\title{
Vibrio hangzhouensis sp. nov., isolated from sediment of the East China Sea
}

\author{
Xue-Wei Xu, ${ }^{1,2}$ Yue-Hong Wu, ${ }^{3}$ Chun-Sheng Wang, ${ }^{1,2}$ Aharon Oren ${ }^{4}$ \\ and $\mathrm{Min} \mathrm{Wu}^{3}$ \\ ${ }^{1}$ Laboratory of Marine Ecosystem and Biogeochemistry, State Oceanic Administration, Hangzhou \\ 310012, PR China \\ ${ }^{2}$ Second Institute of Oceanography, State Oceanic Administration, Hangzhou 310012, PR China \\ ${ }^{3}$ College of Life Sciences, Zhejiang University, Hangzhou 310058, PR China \\ ${ }^{4}$ Institute of Life Sciences, and the Moshe Shilo Minerva Center for Marine Biogeochemistry, The \\ Hebrew University of Jerusalem, Jerusalem 91904, Israel
}

Correspondence

Xue-Wei Xu

xuxw@sio.org.cn
Strain $\mathrm{CN83}^{\top}$, a Gram-negative, aerobic, rod-shaped bacterium, was isolated from sediment of the East China Sea. The isolate was catalase- and oxidase-positive and cells were motile by means of polar flagella. The DNA G+C content was 44.9 mol\%. The major fatty acids were $\mathrm{C}_{16: 1} \omega 7 c$ and/or iso- $\mathrm{C}_{15: 0} 2-\mathrm{OH}, \mathrm{C}_{16: 0}, \mathrm{C}_{18: 1} \omega 7 c, \mathrm{C}_{14: 0}$ and $\mathrm{C}_{12: 0} .16 \mathrm{~S}$ rRNA gene sequence analysis showed that strain $\mathrm{CN} 3^{\top}$ belonged to the genus Vibrio and had the highest sequence similarity to Vibrio agarivorans (98.4\%) and Vibrio campbellii (97.8\%). Phylogenetic

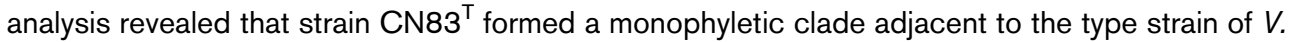
agarivorans. The DNA-DNA hybridization values of strain $\mathrm{CN}^{2} 3^{\top}$ with $\mathrm{V}$. agarivorans DSM $13756^{\top}$ and $V$. campbellii DSM $19270^{\top}$ were 44.6 and $25.5 \%$, respectively. On the basis of the phenotypic and genotypic data, strain $\mathrm{CN}_{8}{ }^{\top}$ represents a novel species of the genus Vibrio, for which the name Vibrio hangzhouensis sp. nov. is proposed. The type strain is $\mathrm{CN}^{2}{ }^{\top}$ (=CGMCC $1.7062^{\top}=$ JCM $15146^{\top}$ ).
Species of Vibrio Pacini 1854 are common inhabitants of aquatic environments and are often found associated with various organisms ranging from plankton to animals (Thompson et al., 2004a). Several species are pathogenic for humans and animals (Farmer \& Hickman-Brenner, 2006). In 1980, the genus Vibrio encompassed nine recognized species (Skerman et al., 1980). Subsequently four species were reclassified to other genera, including Wolinella succinogenes, Listonella anguillarum, Salinivibrio

Abbreviations: gapA, glyceraldehyde-3-phosphate dehydrogenase; gyrB, DNA gyrase B subunit; $p y r H$, uridylate kinase; $r e c A$, recombinase $A$; rpoD, RNA polymerase $\sigma^{70}$.

The GenBank/EMBL/DDBJ accession number for the 16S rRNA gene sequence of strain $\mathrm{CN83}^{\top}$ is EU082035. The accession numbers for the gyrB, gapA, rpoD, pyrH and recA gene sequences of strain $\mathrm{CN} 3^{\top}$ and Vibrio agarivorans DSM $13756^{\top}$ are FJ436361-FJ436366, FJ436368, FJ463225, FJ178183 and FJ178184. The accession number for the rpoD gene sequence of Vibrio campbellii DSM $19270^{\top}$ is FJ436367.

Tables showing the fatty acid compositions of strain $\mathrm{CN} 3^{\top}$ ( $V$. hangzhouensis sp. nov.) and $V$. agarivorans DSM $13756^{\top}$ and differential characteristics of strain $\mathrm{CN83}^{\top}$ and related Vibrio species and phylogenetic trees based on 16S RNA gene sequences using maximum-parsimony and $16 \mathrm{~S}$ rRNA, gyrB, gapA, pyrH, rpoD and recA gene sequences using neighbour-joining are available as supplementary material with the online version of this paper. costicola and Alivibrio fischeri (Tanner et al., 1981; MacDonell \& Colwell, 1985; Mellado et al., 1996; Urbanczyk et al., 2007). However, more Vibrio species were described during the past three decades. At the time of writing, the genus Vibrio included 68 species with validly published names (Farmer et al., 2005; Euzéby, 1997). Here we present a polyphasic study describing a novel Vibrio strain isolated from sediment of the East China Sea.

The sediment sample was collected by using a multicorer from the East China Sea $\left(120^{\circ} 34^{\prime} 29^{\prime \prime}\right.$ E, $\left.27^{\circ} 19^{\prime} 57^{\prime \prime} \mathrm{N}\right)$ at a depth of $49 \mathrm{~m}$. An approximately $100 \mathrm{mg}$ subsample was suspended in $3 \mathrm{ml}$ sterile seawater and vortexed for $15 \mathrm{~min}$. The dispersed sediment suspension was plated on modified ZoBell agar plates using a tenfold dilution series method at $25{ }^{\circ} \mathrm{C}$ for several days (ZoBell, 1941; Huo et al., 2008). Colonies were picked and purified after three subcultures. Purity was confirmed by the uniformity of colony morphology. An isolate that formed non-pigmented colonies was obtained and designated strain $\mathrm{CN} 83^{\mathrm{T}}$. The isolate was cultured routinely on marine agar 2216 (MA; Difco) and maintained as a glycerol suspension $(30 \%, v / v)$ at $-80{ }^{\circ} \mathrm{C}$.

The 16S rRNA, gyrB, gapA, rpoD, pyrH and recA genes were amplified and analysed as described by Lawrence et al. 
(1991), Yamamoto \& Harayama $(1995,1998)$, Thompson et al. (2004b, 2005) and Xu et al. (2007). PCR products were cloned into pMD 19-T vector (TaKaRa) and then sequenced. An almost complete $16 \mathrm{~S}$ rRNA gene sequence (1475 nt) was obtained and compared with closely related sequences of reference organisms from the FASTA and EzTaxon service (Chun et al., 2007). Sequence data were aligned with CLUSTAL W 1.8 (Thompson et al., 1994). Phylogenetic trees were constructed by using the neighbour-joining (Saitou \& Nei, 1987) and maximumparsimony methods (Fitch, 1971) with the MEGA 4 program package (Tamura et al., 2007). Evolutionary distances were calculated according to the algorithm of the Kimura twoparameter model (Kimura, 1980) for the neighbourjoining method.

Comparisons of 16S rRNA gene sequences showed that strain $\mathrm{CN} 83^{\mathrm{T}}$ should be positioned within the genus Vibrio, being most closely related to the type strain of $V$. agarivorans ( $98.4 \%$ similarity); the sequence similarities with respect to type strains of other recognized Vibrio species were 94.1-97.8\%. Phylogenetic analysis based on the neighbour-joining method showed that strain $\mathrm{CN} 83^{\mathrm{T}}$ formed a monophyletic clade adjacent to the type strain of V. agarivorans with high bootstrap support (93\%) (Fig. 1). The topologies of the phylogenetic trees built using the maximum-parsimony method also supported the notion that strain $\mathrm{CN} 83^{\mathrm{T}}$ formed a stable clade with the type strain of $V$. agarivorans (see Supplementary Fig. S1 in IJSEM Online). Analysis of the gyrB, gapA, rpoD, pyrH and recA genes also supported the phylogenetic position of strain $\mathrm{CN} 83^{\mathrm{T}}$ within the genus Vibrio (Supplementary Fig. S2, in IJSEM Online).

The optimal conditions for growth were determined in PY broth (Shieh et al., 2000) with different $\mathrm{NaCl}$ concentrations $(0,0.5,1,3,5,7.5,10,15,20$ and $30 \%, \mathrm{w} / \mathrm{v})$. The $\mathrm{pH}$ range for growth was determined by adding MES ( $\mathrm{pH}$ 5.0-6.0),

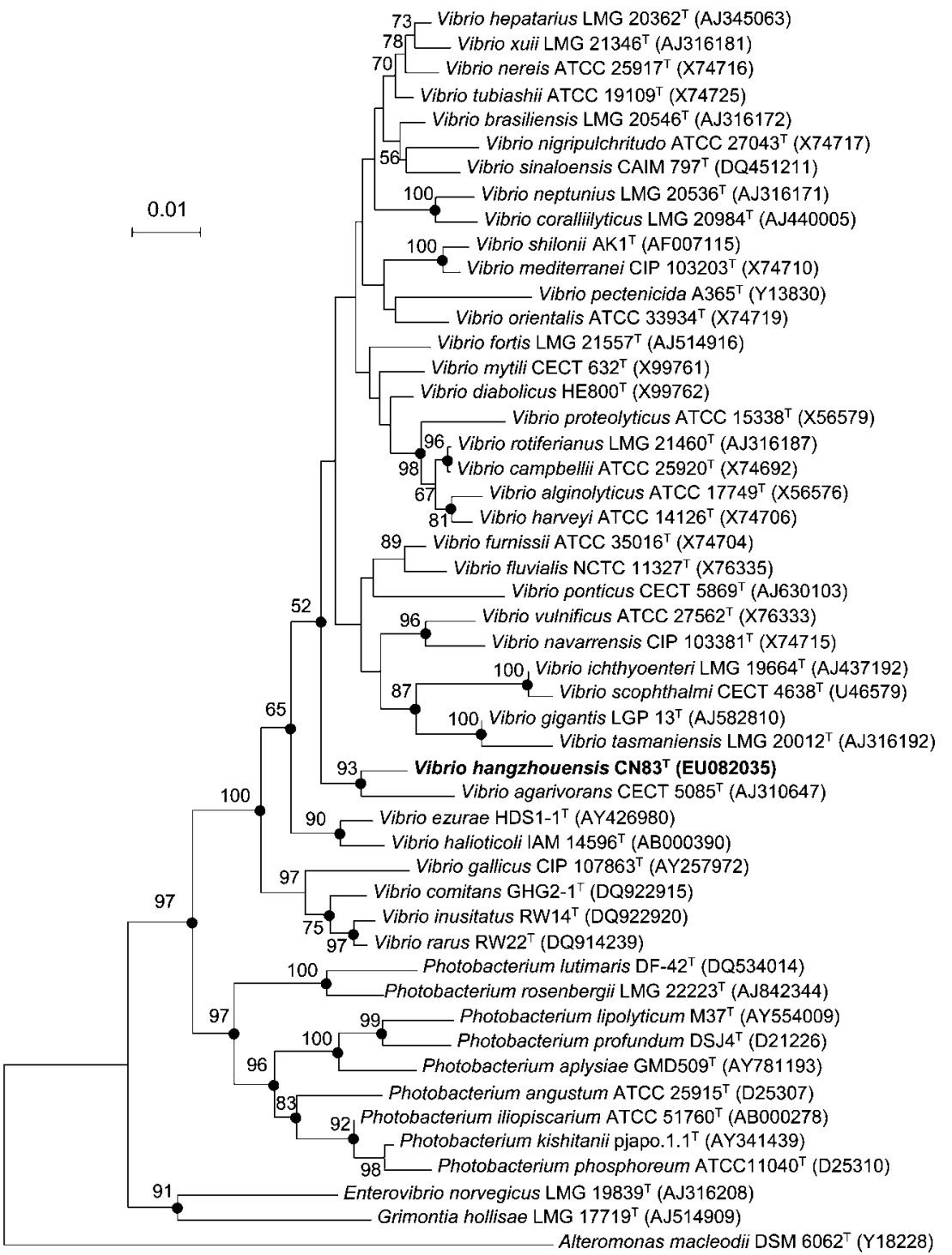

Fig. 1. Neighbour-joining tree based on $16 \mathrm{~S}$ rRNA gene sequences, showing the phylogenetic relationships of the novel isolate and related taxa. Bootstrap values are based on 1000 replicates; only values $>50 \%$ are shown. Bar, 0.01 substitutions per nucleotide position. Filled circles indicate that the corresponding nodes were also recovered with bootstrap values $>50 \%$ in the maximumparsimony tree. 
PIPES (pH 6.5-7.0), Tricine ( $\mathrm{pH} 7.5-8.5)$ and CAPSO $(\mathrm{pH} 9.0-10.5)$ to $\mathrm{PY}$ broth at a concentration of $50 \mathrm{mM}$. The temperature range for growth was determined after $8 \mathrm{~h}$ and 2 days incubation at $4,10,15,20,25,30,35,37,42$, 48 and $55{ }^{\circ} \mathrm{C}$. Cell morphology and motility were examined by optical microscopy (BX40, Olympus) and electron microscopy (S260, Cambridge; JEM-1230, JEOL). The $\mathrm{NaCl}$ concentration, $\mathrm{pH}$ and temperature ranges for growth of strain $\mathrm{CN} 83^{\mathrm{T}}$ were $0.5-7.5 \%(\mathrm{w} / \mathrm{v}), \mathrm{pH} 6.0$ 10.0 and $20-37{ }^{\circ} \mathrm{C}$, respectively. Cells of strains $\mathrm{CN} 83^{\mathrm{T}}$ were Gram-negative rods and motile by means of polar flagella (Fig. 2).

Biochemical tests were performed using the methods described by Macián et al. (2001a, b). Single carbon source assimilation tests were performed using the basal medium of Baumann and Baumann (BM medium; Farmer \& Hickman-Brenner, 2006). The BM medium contained ( $\mathrm{l}^{-1}$ distilled water): $1.0 \mathrm{~g} \mathrm{NH}_{4} \mathrm{Cl}, 0.044 \mathrm{~g} \mathrm{~K}_{2} \mathrm{HPO}_{4}, 0.028 \mathrm{~g}$ $\mathrm{FeSO}_{4} \cdot 7 \mathrm{H}_{2} \mathrm{O}, 500 \mathrm{ml}$ artificial seawater, $100 \mathrm{ml}$ Tris/ $\mathrm{HCl}$ (1 M, pH 7.5). The artificial seawater contained ( $\mathrm{l}^{-1}$ distilled water): $23.4 \mathrm{~g} \mathrm{NaCl}, 24.6 \mathrm{~g} \mathrm{MgSO}_{4} \cdot 7 \mathrm{H}_{2} \mathrm{O}$, $1.5 \mathrm{~g} \mathrm{KCl}$ and $2.9 \mathrm{~g} \mathrm{CaCl}_{2}$. Another basal medium (Kämpfer et al., 1991) was used to confirm assimilation of substrates. The basal medium contained $\left(1^{-1}\right.$ distilled water): $\quad 9.0 \mathrm{~g} \mathrm{NaCl}, \quad 0.5 \mathrm{~g} \quad \mathrm{MgSO}_{4} .7 \mathrm{H}_{2} \mathrm{O}, \quad 0.1 \mathrm{~g}$

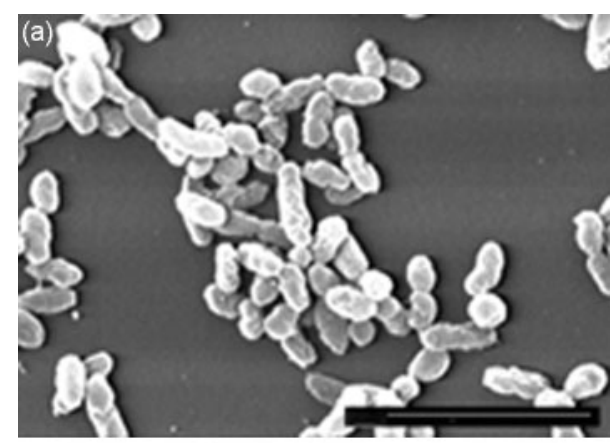

(b)
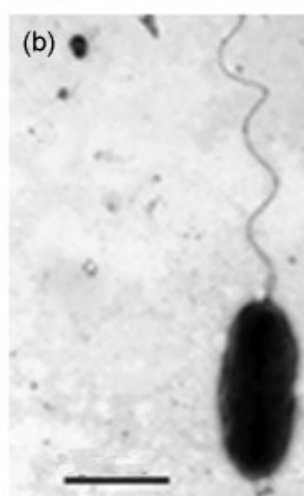

$\longrightarrow$

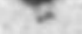

Fig. 2. Electron micrographs of cells of strain $\mathrm{CN}_{8} 3^{\top}$. (a) Scanning electron micrograph of exponentially growing cells, $0.6-0.8 \times 1.2-2.0 \mu \mathrm{m}$ in size; (b) transmission electron micrograph showing a slightly ovoid rod with polar flagellum. Bars, $5 \mu \mathrm{m}$ (a) and $1 \mu \mathrm{m}$ (b).
$\mathrm{CaCl}_{2} \cdot 2 \mathrm{H}_{2} \mathrm{O}, \quad 1.74 \mathrm{~g} \quad \mathrm{~K}_{2} \mathrm{HPO}_{4}, \quad 1.36 \mathrm{~g} \quad \mathrm{KH}_{2} \mathrm{PO}_{4}, \quad 5 \mathrm{~g}$ $\left(\mathrm{NH}_{4}\right)_{2} \mathrm{SO}_{4}, 0.02 \mathrm{~g}$ yeast extract (Difco), $0.02 \mathrm{~g}$ peptone (Difco), $1 \mathrm{ml}$ vitamin mixture solution, $5 \mathrm{ml}$ mineral mixture solution and $25 \mathrm{mM}$ PIPES, $\mathrm{pH}$ 7.2. Acid production was performed using the MOF medium supplemented with $1 \%$ sugars or alcohols (Leifson, 1963). Sensitivity to antimicrobial agents was determined in marine broth 2216 (Difco) containing each antimicrobial agent at $50 \mathrm{mg} \mathrm{l}^{-1}$ for at least 3 days. Additional enzyme activities and biochemical characteristics were determined using API 20E, API 20 NE and API ZYM kits at $30{ }^{\circ} \mathrm{C}$ as recommended by the manufacturer (bioMérieux). V. agarivorans DSM $13756^{\mathrm{T}}$ and V. campbellii DSM $19270^{\mathrm{T}}$ were used as controls in the tests. Detailed results are given in the species description.

The genomic DNA G + C content was determined by using thermal denaturation $\left(T_{\mathrm{m}}\right)$ (Marmur \& Doty, 1962) with Escherichia coli K-12 DNA as calibration standard. Cellular fatty acid methyl esters obtained from cells grown in MA for $24 \mathrm{~h}$ at $30{ }^{\circ} \mathrm{C}$ were analysed by using GC/MS (Kuykendall et al., 1988), according to the instructions of the Microbial Identification System (MIDI Inc.). The major fatty acids of strain $\mathrm{CN} 3^{\mathrm{T}}$ were $\mathrm{C}_{16: 1} \omega 7 c$ and/or

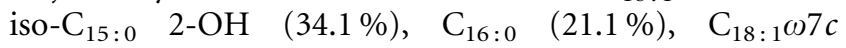
$(18.3 \%), \mathrm{C}_{14: 0}(11.8 \%)$ and $\mathrm{C}_{12: 0}(5.1 \%)$. This profile was different from that of $V$. agarivorans DSM $13756^{\mathrm{T}}$ (Supplementary Table S1, in IJSEM Online).

DNA-DNA hybridizations were performed by using the thermal denaturation and renaturation method of De Ley et al. (1970) as modified by Huß et al. (1983), using a Beckman DU 800 Spectrophotometer. The hybridization temperature $\left(70{ }^{\circ} \mathrm{C}\right)$ was calculated from the DNA G $+\mathrm{C}$ content with the formula of De Ley et al. (1970). The levels of DNA-DNA relatedness of 44.6 and $25.5 \%$ between strain $\mathrm{CN} 83^{\mathrm{T}}$ and $V$. agarivorans DSM $13756^{\mathrm{T}}$ and $V$. campbellii DSM $19270^{\mathrm{T}}$ were significantly below the value of $70 \%$ that is considered to be the threshold for the delineation of species (Wayne et al., 1987). Additionally, strain $\mathrm{CN} 83^{\mathrm{T}}$ could be differentiated from $V$. agarivorans DSM $13756^{\mathrm{T}}$ on the basis of several phenotypic characteristics (Table 1 and Supplementary Table S2).

On the basis of the phenotypic and phylogenetic data presented in this study, strain $\mathrm{CN} 83^{\mathrm{T}}$ represents a novel species within the genus Vibrio, for which the name Vibrio hangzhouensis sp. nov. is proposed.

\section{Description of Vibrio hangzhouensis sp. nov.}

Vibrio hangzhouensis (hang.zhou.en'sis. N.L. masc. adj. hangzhouensis pertaining to Hangzhou, a city in eastern China, near where the sample from which the type strain was isolated was collected).

Gram-negative rods, motile by means of polar flagella. Cells are straight to slightly curved and rod-shaped (0.5$0.8 \mu \mathrm{m}$ in width and $1.0-2.0 \mu \mathrm{m}$ in length) with rounded ends. No endospores are formed. Colonies on MA are 
Table 1. Phenotypic characteristics that differentiate strain $\mathrm{CN83}{ }^{\top}$ from other related Vibrio species

Strains: $1, \mathrm{CN}^{2} 3^{\mathrm{T}}$ (V. hangzhouensis sp. nov.); 2, V. agarivorans DSM $13756^{\mathrm{T}}$; 3, V. campbellii DSM $19270^{\mathrm{T}}$. +, Positive; -, negative; $\mathrm{w}+$, weakly positive.

\begin{tabular}{|c|c|c|c|}
\hline Characteristic & 1 & 2 & 3 \\
\hline $\begin{array}{l}\text { Growth on } \\
\text { MacConkey agar }\end{array}$ & + & - & - \\
\hline Indole production & + & - & + \\
\hline Lecithinase & - & - & + \\
\hline \multicolumn{4}{|l|}{ Hydrolysis of: } \\
\hline Agar & - & + & - \\
\hline Casein & - & - & + \\
\hline DNA & - & - & + \\
\hline Tween 80 & - & $\mathrm{w}+$ & + \\
\hline Tyrosine & + & - & + \\
\hline \multicolumn{4}{|l|}{ Utilization of: } \\
\hline Acetate & + & + & - \\
\hline L-Alanine & + & - & + \\
\hline Citrate & + & - & + \\
\hline D-Galactose & + & + & - \\
\hline Gluconate & + & - & + \\
\hline Glycine & + & - & + \\
\hline L-Histidine & + & - & + \\
\hline Lactate & + & - & + \\
\hline Lactose & + & + & - \\
\hline D-Mannose & + & - & + \\
\hline L-Ornithine & + & - & + \\
\hline Propionate & + & - & - \\
\hline Ribose & + & - & + \\
\hline Sucrose & + & - & - \\
\hline Xylose & - & + & - \\
\hline \multicolumn{4}{|l|}{ Acid production from: } \\
\hline Lactose & + & + & - \\
\hline D-Mannose & + & - & + \\
\hline Rhamnose & - & + & - \\
\hline Ribose & + & - & + \\
\hline Sucrose & + & - & - \\
\hline Trehalose & + & - & + \\
\hline Xylose & - & + & - \\
\hline \multicolumn{4}{|l|}{ Sensitive to: } \\
\hline Ampicillin & - & + & - \\
\hline Nalidixic acid & - & + & - \\
\hline Neomycin & - & + & - \\
\hline Polymyxin B & - & + & - \\
\hline \multicolumn{4}{|l|}{ API ZYM } \\
\hline $\begin{array}{l}N \text {-Acetyl- } \beta \text { - } \\
\text { glucosaminidase }\end{array}$ & - & + & + \\
\hline$\alpha$-Chymotrypsin & - & + & - \\
\hline Cystine arylamidase & - & + & + \\
\hline$\beta$-Galactosidase & - & - & $\mathrm{w}+$ \\
\hline Lipase (C14) & - & + & $\mathrm{w}+$ \\
\hline Leucine arylamidase & - & + & + \\
\hline Trypsin & - & + & - \\
\hline Valine arylamidase & - & + & + \\
\hline
\end{tabular}

1-2 $\mathrm{mm}$ in diameter, smooth and circular, with slightly irregular borders and non-pigmented after $48 \mathrm{~h}$. Growth occurs at $\mathrm{NaCl}$ concentrations of $0.5-7.5 \%(\mathrm{w} / \mathrm{v})$ with optimum growth with $3.0 \% \mathrm{pH}$ and temperature ranges for growth are $\mathrm{pH} 6.0-10.0$ and $20-37^{\circ} \mathrm{C}$ (optimum growth at $\mathrm{pH} 7.0-8.0$ and $30{ }^{\circ} \mathrm{C}$ ). No growth is detected below 15 or above $42{ }^{\circ} \mathrm{C}$. Growth occurs on MacConkey agar (red colonies). No growth occurs on Cetrimide agar. Positive for oxidase and catalase. Nitrate is reduced to nitrite but not further to $\mathrm{N}_{2} \mathrm{O}$ or $\mathrm{N}_{2}$. Aesculin, gelatin, starch, Tween 20 and tyrosine are hydrolysed. Agar, casein, DNA and Tween 80 are not hydrolysed. $\mathrm{H}_{2} \mathrm{~S}$ is produced from thiosulfate or L-cysteine. Glucose fermentation, indole production and $o$-nitrophenyl- $\beta$-D-galactopyranosidase are positive. Negative for arginine dihydrolase, lecithinase, lysine decarboxylase, ornithine decarboxylase, tryptophan deaminase, urease and Voges-Proskauer reaction. The follow constitutive enzyme activities are detected in API ZYM tests: acid and alkaline phosphatases, esterase (C4), esterase lipase (C8) and naphthol-AS- $\beta$-1-phosphohydrolase. $N$-Acetyl- $\beta$-glucosaminidase, $\alpha$-chymotrypsin, cystine arylamidase, $\alpha$-fucosidase, $\alpha$ - and $\beta$-galactosidases, $\alpha$ - and $\beta$-glucosidases, $\beta$-glucuronidase, lipase (C14), leucine arylamidase, $\alpha$-mannosidase, trypsin and valine arylamidase activities are not observed. Chemo-organotrophic. The following compounds are utilized as sole carbon and energy sources: acetate, L-alanine, L-arginine, Lasparagine, L-aspartate, D-cellobiose, citrate, L-cysteine, Dfructose, fumarate, D-galactose, D-gluconate, glucose, Lglutamate, glycerol, glycine, L-glutamine, L-histidine, lactate, lactose, malate, maltose, D-mannitol, D-mannose, Lornithine, L-proline, propionate, pyruvate, ribose, L-serine, succinate, sucrose and D-trehalose. The following compounds are not utilized as sole carbon and energy sources: adonitol, L-arabinose, ethanol, formate, inositol, L-isoleucine, L-lysine, malonate, L-methionine, L-rhamnose, ribitol, L-sorbitol, sorbose, L-valine, xylitol and xylose. Acid is produced from D-fructose, D-galactose, glucose, lactose, maltose, D-mannitol, D-mannose, ribose, sucrose and trehalose. Susceptible to chloramphenicol, erythromycin, nitrofurantoin, novobiocin and the vibriostatic agent $\mathrm{O} /$ 129; not susceptible to ampicillin, bacitracin, carbenicillin, cefotaxime, kanamycin, nalidixic acid, neomycin, nystatin, polymyxin $\mathrm{B}$, streptomycin and tetracycline. Principal fatty acids (greater than $5 \%$ ) are $\mathrm{C}_{16: 1} \omega 7 c$ and/or iso- $\mathrm{C}_{15: 0} 2$ $\mathrm{OH}, \mathrm{C}_{16: 0}, \mathrm{C}_{18: 1} \omega 7 c, \mathrm{C}_{14: 0}$ and $\mathrm{C}_{12: 0}$. The DNA G+C content of the type strain is $44.9 \mathrm{~mol} \%\left(T_{\mathrm{m}}\right)$.

The type strain, $\quad \mathrm{CN} 83^{\mathrm{T}} \quad\left(=\mathrm{CGMCC} \quad 1.7062^{\mathrm{T}}=\mathrm{JCM}\right.$ $\left.15146^{\mathrm{T}}\right)$, was isolated from a marine sediment sample from Zhejiang, China.

\section{Acknowledgements}

This work was supported by grants from the Ministry of Science and Technology of China (973 Program, 2004CB719604-3; 863 Program, 2007AA021305), the National Natural Science Foundation of China (40806066), Zhejiang Provincial Natural Science Foundation of China (Y5080060), the Scientific Research Fund of the Second Institute of 
Oceanography, SOA (JT0709) and the Chinese Offshore Investigation and Assessment (908-ZC-I-02).

\section{References}

Chun, J., Lee, J.-H., Jung, Y., Kim, M., Kim, S., Kim, B. K. \& Lim, Y.-W. (2007). EzTaxon: a web-based tool for the identification of prokaryotes based on $16 \mathrm{~S}$ ribosomal RNA gene sequences. Int J Syst Evol Microbiol 57, 2259-2261.

De Ley, J., Cattoir, H. \& Reynaerts, A. (1970). The quantitative measurement of DNA hybridization from renaturation rates. Eur J Biochem 12, 133-142.

Euzéby, J. P. (1997). List of Bacterial Names with Standing in Nomenclature: a folder available on the Internet. Int J Syst Bacteriol 47, 590-592.

Farmer, J. J., III \& Hickman-Brenner, F. W. (2006). The genera Vibrio and Photobacterium. In The Prokaryotes: a Handbook on the Biology of Bacteria, 3rd edn, vol. 6, pp. 508-563. Edited by M. Dworkin, S. Falkow, E. Rosenberg, K. H. Schleifer \& E. Stackebrandt. New York: Springer.

Farmer, J. J., III, Janda, J. M., Brenner, F. W., Cameron, D. N. \& Birkhead, K. M. (2005). Genus I. Vibrio Pacini 1854, $411^{\mathrm{AL}}$. In Bergey's Manual of Systematic Bacteriology, 2nd edn, vol. 2, The Proteobacteria, Part B, The Gammaproteobacteria, pp. 494-546. Edited by D. J. Brenner, N. R. Krieg, J. T. Staley \& G. M. Garrity. New York: Springer.

Fitch, W. M. (1971). Toward defining the course of evolution: minimum change for a specific tree topology. Syst Zool 20, 406-416.

Huo, Y.-Y., Wang, C.-S., Yang, J.-Y., Wu, M. \& Xu, X.-W. (2008). Marinobacter mobilis sp. nov. and Marinobacter zhejiangensis sp. nov., halophilic bacteria isolated from the East China Sea. Int J Syst Evol Microbiol 58, 2885-2889.

Huß, V. A. R., Festl, H. \& Schleifer, K. H. (1983). Studies on the spectrophotometric determination of DNA hybridization from renaturation rates. Syst Appl Microbiol 4, 184-192.

Kämpfer, P., Steiof, M. \& Dott, W. (1991). Microbiological characterization of a fuel-oil contaminated site including numerical identification of heterotrophic water and soil bacteria. Microb Ecol 21, 227-251.

Kimura, M. (1980). A simple method for estimating evolutionary rates of base substitutions through comparative studies of nucleotide sequences. J Mol Evol 16, 111-120.

Kuykendall, L. D., Roy, M. A., O’Neill, J. J. \& Devine, T. E. (1988). Fatty acids, antibiotic resistance, and deoxyribonucleic acid homology groups of Bradyrhizobium japonicum. Int $J$ Syst Bacteriol 38, 358-361.

Lawrence, J. G., Hartl, D. L. \& Ochman, H. (1991). Molecular considerations in the evolution of bacterial genes. J Mol Evol 33, 241-250.

Leifson, E. (1963). Determination of carbohydrate metabolism of marine bacteria. J Bacteriol 85, 1183-1184.

MacDonell, M. T. \& Colwell, R. R. (1985). Phylogeny of the Vibrionaceae, and recommendation for two new genera, Listonella and Shewanella. Syst Appl Microbiol 6, 171-182.

Macián, M. C., Ludwig, W., Schleifer, K. H., Pujalte, M. J. \& Garay, E. (2001a). Vibrio agarivorans sp. nov., a novel agarolytic marine bacterium. Int J Syst Evol Microbiol 51, 2031-2036.

Macián, M. C., Ludwig, W., Aznar, R., Grimont, P. A. D., Schleifer, K. H., Garay, E. \& Pujalte, M. J. (2001b). Vibrio lentus sp. nov., isolated from Mediterranean oysters. Int J Syst Evol Microbiol 51, 1449-1456.
Marmur, J. \& Doty, P. (1962). Determination of the base composition of deoxyribonucleic acid from its thermal denaturation temperature. J Mol Biol 5, 109-118.

Mellado, E., Moore, E. R., Nieto, J. J. \& Ventosa, A. (1996). Analysis of 16S rRNA gene sequences of Vibrio costicola strains: description of Salinivibrio costicola gen. nov., comb. nov. Int J Syst Bacteriol 46, 817-821.

Saitou, N. \& Nei, M. (1987). The neighbor-joining method; a new method for reconstructing phylogenetic trees. Mol Biol Evol 4, 406-425.

Shieh, W. Y., Chen, A.-L. \& Chiu, H.-H. (2000). Vibrio aerogenes sp. nov., a facultatively anaerobic marine bacterium that ferments glucose with gas production. Int J Syst Evol Microbiol 50, 321-329.

Skerman, V. B. D., McGowan, V. \& Sneath, P. H. A. (editors) (1980). Approved Lists of Bacterial Names. Int J Syst Bacteriol 30, 225-420.

Tamura, K., Dudley, J., Nei, M. \& Kumar, S. (2007). MEGA4: Molecular Evolutionary Genetics Analysis (MEGA) software version 4.0. Mol Biol Evol 24, 1596-1599.

Tanner, A. C. R., Badger, S., Lai, C.-H., Listgarten, M. A., Visconti, R. A. \& Socransky, S. S. (1981). Wolinella gen. nov., Wolinella succinogenes (Vibrio succinogenes Wolin et al.) comb. nov., and description of Bacteroides gracilis sp. nov., Wolinella recta sp. nov., Campylobacter concisus sp. nov., and Eikenella corrodens from humans with periodontal disease. Int J Syst Bacteriol 31, 432-445.

Thompson, J. D., Higgins, D. G. \& Gibson, T. J. (1994). ClustaL W: improving the sensitivity of progressive multiple sequence alignment through sequence weighting, position-specific gap penalties and weight matrix choice. Nucleic Acids Res 22, 4673-4680.

Thompson, F. L., lida, T. \& Swings, J. (2004a). Biodiversity of vibrios. Microbiol Mol Biol Rev 68, 403-431.

Thompson, C. C., Thompson, F. L., Vandemeulebroecke, K., Hoste, B., Dawyndt, P. \& Swings, J. (2004b). Use of recA as an alternative phylogenetic marker in the family Vibrionaceae. Int J Syst Evol Microbiol 54, 919-924.

Thompson, F. L., Gevers, D., Thompson, C. C., Dawyndt, P., Naser, S., Hoste, B., Munn, C. B. \& Swings, J. (2005). Phylogeny and molecular identification of vibrios on the basis of multilocus sequence analysis. Appl Environ Microbiol 71, 5107-5115.

Urbanczyk, H., Ast, J. C., Higgins, M. J., Carson, J. \& Dunlap, P. V. (2007). Reclassification of Vibrio fischeri, Vibrio logei, Vibrio salmonicida and Vibrio wodanis as Aliivibrio fischeri gen. nov., comb. nov., Alivibrio logei comb. nov., Alivibrio salmonicida comb. nov. and Alivibrio wodanis comb. nov. Int J Syst Evol Microbiol 57, 2823-2829.

Wayne, L. G., Brenner, D. J., Colwell, R. R., Grimont, P. A. D., Kandler, O., Krichevsky, M. I., Moore, L. H., Moore, W. E. C., Murray, R. G. E. \& other authors (1987). International Committee on Systematic Bacteriology. Report of the ad hoc committee on reconciliation of approaches to bacterial systematics. Int J Syst Bacteriol 37, 463-464.

Xu, X.-W., Wu, Y.-H., Zhou, Z., Wang, C.-S., Zhou, Y.-G., Zhang, H.-B., Wang, Y. \& Wu, M. (2007). Halomonas saccharevitans sp. nov., Halomonas arcis sp. nov. and Halomonas subterranea sp. nov., halophilic bacteria isolated from hypersaline environments of China. Int J Syst Evol Microbiol 57, 1619-1624.

Yamamoto, S. \& Harayama, S. (1995). PCR amplification and direct sequencing of $g y r B$ genes with universal primers and their application to the detection and taxonomic analysis of Pseudomonas putida strains. Appl Environ Microbiol 61, 1104-1109.

Yamamoto, S. \& Harayama, S. (1998). Phylogenetic relationships of Pseudomonas putida strains deduced from the nucleotide sequences of gyrB, rpoD and 16S rRNA genes. Int J Syst Bacteriol 48, 813-819.

ZoBell, C. E. (1941). Studies on marine bacteria. I. The cultural requirements of heterotrophic aerobes. J Mar Res 4, 42-75. 